\title{
Święci a tożsamość etniczna i lokalna
}

Osoba świętego, znana nie tylko w religii chrześcijańskiej, jest symbolem jednoczącym wiernych jednego, choć nie tylko, wyznania. Analiza wielkich religii światowych wykazuje, że we wszystkich: hinduizmie, taoizmie i konfucjanizmie, buddyzmie, a w szczególny sposób w islamie, pojawiają się postacie, które są ludźmi specyficznie wyróżnionymi i wierni oddają im specjalną cześćc ${ }^{\text {. }}$ Owa nadprzeciętność może objawiać się w cudownych własnościach uzdrawiania, widzeniach, prorokowaniach czy też w życiu pełnym ascetycznych wyrzeczeń lub męczeńskiej śmierci. Ta ostatnia charakterystyka osoby świętego jest szczególnie ważna w chrześcijaństwie, gdyż w tej religii podkreślane jest godne pochwały zaangażowanie w naśladowanie cierpiącego Chrystusa - imitatio Christi. Założyciele wielkich religii monoteistycznych: Jezus, Mahomet, Budda, sa przecież także ludźmi, postaciami historycznymi, podobnie jak wielcy prorocy. Osoby „świętych” i „błogosławionych” (używam owych nazw w tym miejscu, zdając sobie sprawę, że dla różnych religii tworzenie prostych analogii między okazywaniem czci ludziom, a nie Boskości, może okazać się daleko mylące) stoją jednak niżej w hierarchii dążenia do boskiej doskonałości. Są zatem bliższe przeciętemu człowiekowi, a co za tym idzie, znakomicie nadają się do świadomego lub też pozostającego poza sferą refleksji wykorzystywania w procedurach wzmacniających lokalne czasoprzestrzenne identyfikacje.

Te ostatnie polegają na swoistym tworzeniu więzi z danym krajem, regionem czy też niżej - społecznością lokalną, dla których te postaci stały się znaczące, stały się symbolami. Owo poczucie łączności poprzez usymbolicznioną osobę

* Dr Tomasz Marciniak, adiunkt w Instytucie Socjologii Uniwersytetu Mikołaja Kopernika w Toruniu.

${ }^{1}$ H. Fros, Pamiętajac o mieszkańcach nieba. Kult świętych w dziejach i liturgii, Tarnów 1994, s. $18-21$. 
może być też wyniesione ponad poziom lokalny, gdy grupa społeczna żyje w rozproszeniu, $\mathrm{w}$ diasporze, i takie przykłady przyniesie prezentowany tekst.

O ile postaci kapłanów czy lokalnych bohaterów mogą ulegać symbolizacji naturalnej, to osoby świętych i błogosławionych chrześcijańskich, tak zdefiniowane przez instytucjonalny Kościół, stają się symbolami niejako z urzędu, ponieważ uznane zostają za takie przez ogłoszenie odpowiednich przepisów kościelnych ${ }^{2}$.

Poniższa analiza zostanie poświęcona świętym, osobom-symbolom, służącym do podtrzymywania więzi między członkami jednej grupy narodowej lub szerzej mówiąc - etnicznej. Zanim to jednak nastąpi, chciałbym w tym miejscu przybliżyć nieco teoretyczne kategorie „symbolicznego zawłaszczania” oraz „kulturowej czasoprzestrzeni”.

Wraz z ogłoszeniem przez Alberta Einsteina teorii względności - szczególnej (1905) i ogólnej (1916) - radykalnie zaczęło się zmieniać ludzkie postrzeganie rzeczywistości. Przyszedł czas na uzupełnienie newtonowskich teorii. Filozofowie powrócili do roztrząsania zagadnień czasu i przestrzeni. Przestrzeń to widzialna teraźniejszość. Czas to przestrzeń, która się porusza, stając się przyszłością lub przeszłością. Przestrzeń to czas poziomy, horyzontalny, czas to przestrzeń prostopadła, wertykalna. Przestrzeń to czas trwajacy, czas to przestrzeń $m k n q c a^{3}$, pisał o czwartym wymiarze w latach dwudziestych poeta - Maurycy Maeterlinck, wzbudzając swym opartym o wiele naukowych hipotez traktatem namiętne dyskusje wśród ówczesnych intelektualistów.

Po rewolucji, jaką wywołało pojawienie się einsteinowskiego paradygmatu, czas coraz powszechniej zaczął być postrzegany jako „czwarty wymiar” otaczającego nas świata. Pojawiło się pojęcie czasoprzestrzeni jako jedni - continuum, którego aspektami są dwa, dotąd postrzegane jako oddzielne, fenomeny. Do dziś teoria Einsteina jest interpretowana i komentowana przez fizyków, odkrywających coraz to nowe argumenty na rzecz jej słuszności. Doczekuje się także kolejnych komentarzy filozofów ${ }^{4}$.

Jakie miejsce w tym sporze o wzajemne relacje między czasem a przestrzenią zajmuję ja, badający swoistości społecznej czasoprzestrzeni kulturowej? Próbując sprowadzić odpowiedź na płaszczyznę jak najbardziej operacyjna, proponuję w tym miejscu rozwiązanie pośrednie. Otóż wydaje mi się, że czas na różnych obszarach biegnie w inny sposób. Otaczające ludzi środowisko fizyczne i tworzone przez nich środowiska kulturowe konstruują czas w sposób inny, niż ma to miejsce na obszarach zurbanizowanych i uprzemysłowionych. Czasoprzestrzeń kulturowa nasycona sacrum jest więc społecznie konstruowana w wyjątkowy sposób, a osoby-symbole spełniają tu rolę znaczącą. Ma to charakter rzeczywi-

${ }^{2}$ Takim dokumentem Soboru Watykańskiego II jest Konstytucja Lumen gentium z 21 października 1964 roku, podpisana przez Pawła VI.

${ }^{3}$ M. Maeterlinck, Życie przestrzeni, Kraków 1994, s. 73.

${ }^{4}$ Z. Augustynek, Czasoprzestrzeń. Eseje filozoficzne, Warszawa 1997. 
ście ontologiczny i wiem, że takie stwierdzenie może być słusznie odczytane jako irracjonalne credo.

Współczesna etnologia ujmuje kategorie czasu i przestrzeni jako wzajemnie uzupełniające się. Zofia Sokolewicz pisze: „każdorazowe zawężenie układu społecznego [...] powodowało tym samym zawężenie czasu badań do okresu, w którym wyróżniony układ konkretnie istniał oraz do terytorium - przestrzeni, na której w tym czasie występował. Zmiana układu społecznego czy kulturowego stanowiącego układ odniesienia w prowadzonych badaniach kulturowych powodowała zmianę przestrzeni. W dotychczasowych badaniach etnograficznych zmniejszenie obszaru powodowało skrócenie czasu, w którym badano obiekt. Wielkość przestrzeni charakteryzującej badany układ była proporcjonalna do wielkości czasu"s.

Więc i ludzka świadomość ma ważną rolę do spełnienia w procesie konstruowania czasoprzestrzeni. Nadając specyficzne znaczenie pewnym przedmiotom, zjawiskom, działaniom - uznając je za symbole - ludzie wpływają na czasoprzestrzeń kulturowa, a przez nią na fizyczna, zmieniają więc przez to również i ,rzeczywiste" parametry czasu. Hipotetycznie powinno to być najłatwiej dostrzegalne w lokalnych społecznościach oraz partnerskich związkach, gdzie załamała się jednorodność kulturowa - a tak jest w badanych przeze mnie środowiskach kulturowych, jakim dla potrzeb tego tekstu stały się przede wszystkim Mazury oraz Armenia, znane mi z własnych, kilkuletnich badań terenowych.

Starając się znaleźć powiązania pojęć czasu i przestrzeni z kategorią symbolu, szczególnie w wymiarze religijnym, zgadzam się z konstatacją Dariusza Czaji, przywołującego koncepcje Mircei Eliadego: „doświadczenie czasu i przestrzeni ma charakter ściśle religijny. Symboliczna percepcja rzeczywistości objawia świat jako żywą całość, integruje różne poziomy doświadczenia, włącza jednostkę w życie kosmosu, odsłaniając ciagłość między strukturami ludzkiej egzystencji i strukturami kosmicznymi" ${ }^{\text {" }}$. W moich badawczych ustaleniach staram się wykazać związki między religią, czasem, przestrzenią a symbolem na mikropoziomie społeczności lokalnych.

Symboliczna rola, jaką pełnią dla życia społecznego święci i beatyfikowani, była podkreślana przez badaczy już dawno. Należy tu przede wszystkim wspomnieć o studium Stefana Zygmunta Czarnowskiego, pochodzącym z 1919 roku, a poświęconym postaci św. Patryka, patrona Irlandii ${ }^{7}$. Czarnowskiego warto również przywołać w tym miejscu jako jednego z nielicznych polskich socjologów bezpośrednio kontynuujących myśl Emile’a Durkheima i rozwijających jego

${ }^{5}$ Z. Sokolewicz, Kategorie czasu długiego i czasu krótkiego w tradycji etnografii polskiej, w: Z. Jasiewicz, B. Linette, Z. Staszczak (red.), Tradycja i przemiana, Poznań 1978, s. 46.

${ }^{6}$ D. Czaja, Spór o model antropologicznej interpretacji, Zeszyty Naukowe UJ 27 (1990), z. 27 , s. 8 .

${ }^{7}$ Por. S. Czarnowski, Kult bohaterów i jego spoleczne podłoże. Święty Patryk, bohater narodowy Irlandii, tłum. A. Glinczanka, w: Tenże, Dzieła, t. 4, Warszawa 1956. 
koncepcję przedstawień zbiorowych, czyli poniekąd rodzimego naśladowcy i prekursora socjologicznego rozpatrywania zagadnień przestrzeni i czasu. Postać św. Patryka wraz z globalizacją lokalnych wzorców kulturowych stała się symbolem swego kraju nie tylko dla jego mieszkańców. Duża diaspora irlandzka, zamieszkująca USA, obchodzi dzień św. Patryka jako święto grupy etnicznej. Osoba ta jest postacią historyczną. Był to misjonarz żyjący w latach około 389-461. Jego misja, rozpoczęta w 432 roku w Ulsterze w Irlandii, doprowadziła do chrystianizacji tego kraju. Wiele legend przypisuje mu cuda uzdrowienia, przywracania życia. Miał on podobno uwolnić kraj od plagi węży. Ikonografia prezentuje często tę postać trzymającą koniczynę - symbolizującą Trójcę Święta, a obecnie stanowiącą godło Irlandii ${ }^{8}$. Jak wspomniałem powyżej, dzięki licznej diasporze amerykańskiej, kult Św. Patryka rozpowszechnił się w USA. Do Polski jego celebracje dotarły w postaci znacznie zredukowanej, w połowie lat 90-tych wraz ze wzrostem liczby pubów piwnych. Św. Patryk stał się kolejną kliszą kultury masowej, przyciągając klientów nęconych promocyjnymi w dniu jego święta (17 marca) cenami piwa. Zapewne nieliczni z polskich bywalców Irish Pubs wiedzą, jaką rolę odegrała owa postać w podtrzymywaniu tożsamości grupy etnicznej w rzeczywistości oraz pośrednio, jako osoba-symbol zawłaszczająca kulturową czasoprzestrzeń.

Analizy znaczenia swej postaci doczekał się czczony w sposób szczególny w kościele wschodnim Św. Mikołaj Cudotwórca ${ }^{9}$. Jednak, mimo mnogości jego wizerunków w cerkwiach (jest to bodajże najpopularniejsza ikona „chramowa”, świadcząca o patronie, pod którego wezwaniem postawiono świątynię), nie stał się symbolem ani narodu, ani grupy etnicznej. Jest to spowodowane faktem, że ten święty - postać, której autentyczność bywa dzisiaj poddawana w wątpienie, był biskupem odległej od słowiańszczyzny Myrry. Historycznymi postaciami z pewnością natomiast są Olga i Włodzimierz - książęca para, założyciele Rusi Kijowskiej. Osoby te są czczone zarówno w Kościele prawosławnym, jak i greckokatolickim. Znamienne jest, że nasilenie ich kultu miało swe apogeum stosunkowo niedawno, ponieważ w 1988 roku, z okazji obchodów 1000-lecia chrztu Rusi - rocznicy uroczyście celebrowanej zarówno w Rosji, jak i na Ukrainie ${ }^{10}$. W tym przypadku możemy mówić o silnym sprzężeniu osoby-symbolu z grupa etniczną, jaką byli dawni Rusini, biorąc pod uwagę późniejsze rozgraniczania na dwa narody: ukraiński i rosyjski. Przedstawienia Olgi i Włodzimierza pojawiły się zatem i pod św. Górą Grabarką koło Siemiatycz, ale też na stojącej w centrum Moskwy nowej, dwupoziomowej cerkwi katedralnej, gdzie liturgie celebruje Aleksiej II, Patriarcha Wszechrusi. Warto tu zauważyć, że Mieszko I - założy-

${ }^{8}$ W. Kopaliński, Stownik mitów i tradycji kultury, Warszawa 1987, s. 482.

${ }^{9}$ B. A. Uspienski, Kult św. Mikołaja na Rusi, Lublin 1985.

${ }^{10} \mathrm{Z}$ tej okazji Sobór Lokalny Cerkwi Rosyjskiej kanonizował nowych świętych. Jedyną postacią-symbolem łączącą świat polityki z religią stał się odtąd Dymitr Doński. Por. K. Bondarczuk, Nowi święci Cerkwi Rosyjskiej, Tygodnik Podlaski - Tygodnik Polski, 988-1988. 1000-lecie Chrztu Rusi (wyd. specjalne), s. 18. 
ciel państwa polskiego, nigdy nawet nie pretendował do beatyfikacji, natomiast kanonizowany został św. Wojciech - biskup-męczennik, który stał się oficjalnym patronem Polski.

Kościelna instytucjonalizacja procedury ustanowienia danej osoby jako symbolu nie musi jednak oznaczać w miarę powszechnej akceptacji tej postaci przez grupę zawłaszczającą etniczną czasoprzestrzeń. Naród ormiański, podobnie jak etnos „rusiński”, ma taką postać. Jest nim św. Grzegorz Oświeciciel - symbol religijno-państwowy ${ }^{11}$. Założyciel Kościoła ormiańskiego przez wiele lat przebywał w klasztorze Hor Wirap, oddalonym o kilkadziesiąt kilometrów od obecnej stolicy państwa - Erywania. 27 września 2001 roku monastyr odwiedził Jan Paweł II. Relikwie św. Grzegorza, przekazane katolikosowi Gareginowi II przez Jana Pawła II kilka miesięcy wcześniej w Watykanie, zostały złożone w nowej katedrze podczas jej wyświęcania 22 września 2001, w momencie kulminacji obchodów uroczystości związanych z jubileuszem istnienia Armenii jako państwa chrześcijańskiego. To właśnie ten kraj w 301 roku jako pierwszy na świecie uznał chrześcijaństwo jako religię państwową. Klasztor funkcjonuje do dziś. Zadziwiające, jaką autonomią cieszyła się religia w radzieckiej Armenii. Skarbce w Eczmiadzynie, niedostępne zwykłym turystom, pozostały do dziś pełne skarbów...

Kościół ormiański - jeden z kościołów Wschodu - pozostaje niezależny od biskupa rzymskiego od początku IV wieku ${ }^{12}$. Liturgia stworzona przez św. Grzegorza jest tu używana powszechnie, a jego wyznawcy są czasem określani jako gregorianie (i sami siebie też tak określają). O znaczeniu tej postaci dla konstruowania etnicznej samoświadomości może świadczyć chociażby fakt, że jedno z religijnych czasopism polskich Ormian, wydawane przed wojną we Lwowie, nosiło tytuł: „Trzódka Św. Grzegorza”, natomiast inne - „Gregoriana”.

Inny z ormiańskich świętych, Mesrop Masztoc, został kanonizowany przez Apostolski Kościół Armenii już w VII wieku n.e. Jest to m.in. twórca unikatowego, 39-znakowego alfabetu, podobnego do grafii gruzińskiej, której św. Masztoc też zresztą jest autorem. Do tej pory w stołecznym muzeum Matenadaram w Erywaniu uchowały się odpisy dzieł greckich filozofów, nieznane na Zachodzie. Być może ten ostatni fakt jest spowodowany wysokim stopniem trudności staroormiańskiego (grabar - obecnie martwy język liturgii) oraz samym położeniem zakaukaskiego kraju. Prospekt im. Masztoca to główna arteria stolicy, ale bez wątpienia nie tylko dlatego ta symboliczna postać funkcjonuje w świadomo-

${ }^{11}$ Por. P. M. Marabian, Kawkazkij kulturnyj mir i kult Grigorija Proswitielia, Kawkaz i Wizantija nr 3 (1982), s. 5-20.

${ }^{12} \mathrm{O}$ różnicach między Apostolskim Kościołem Armenii a Kościołem rzymskokatolickim oraz o różnych rytach kościoła łacińskiego wspominam np. w artykułach: Religijność greckokatolicka. Mazurskie przejawy niecodziennego życia, NOMOS 22/23 (1998), s. 135-156; Greko-katolićka religijnist'. Mazurski projawy nieszczodiennoho zittja, Rizdwo Christowe 2000, Lwiw 2001, s. 122-128; Ormianie w Polsce - religia i język, w: M. Kempny, G. Woroniecka (red.), Religia i kultura w globalizujacym się świecie, Kraków 1999, s. 227-238. 
ści każdego Ormianina. Za czasów ZSRR stał się on bowiem świeckim patronem szkolnych uczniów, którzy posiedli już sztukę pisania. Na jego grób w pobliżu Erywania przybywają i przybywały nawet $\mathrm{w}$ czasach radzieckich na początku roku szkolnego wycieczki dzieci. Po odzyskaniu niepodległości przez Armenię w 1991 roku te wyprawy coraz bardziej nabierają charakteru religijnego, stając się pielgrzymkami. Można też wspomnieć, że zdjęcie jego pomnika na tle alfabetu znalazło się jako winieta na stronie internetowej Ormiańskiego Towarzystwa Kulturalnego, stowarzyszenia potomków polskich Ormian kresowych, którzy zaprzestali używania swego alfabetu w XVII wieku... W Armenii taki kult postaci świętego jest kolejną małą ścieżką dla kościelnego integryzmu, zachodzącego naturalną, niewymuszoną drogą.

Należy zauważyć, że sprzężenie pomiędzy postacią świętego a oficjalnym życiem narodowo-państwowym dokonuje się z różną mocą. Każde państwo, gdzie Kościół rzymskokatolicki odgrywa znaczącą rolę, ma swojego patrona ${ }^{13}$. Osobom świętych można by też przypisywać hipotetyczną rolę zawłaszczania czasoprzestrzeni w aspekcie lokalnych społeczności etnicznych. Przykłady z moich mazurskich badań są tu jednak nieliczne. Jak mi się wydaje, greckokatolicki kult świętego Jozafata (Kuncewicza) praktykowany jest prawie wyłącznie przez zakonnice w Kruklankach, jego wizerunki wiszą tylko w większych cerkwiach (Węgorzewo, Kętrzyn), nie spotkałem się z takimi w żadnym z odwiedzanych mieszkań. Natomiast postaciami-symbolami zawłaszczającymi niecodzienny czas członków społeczności lokalnych są święci katoliccy, pod których wezwaniem funkcjonuje dana świątynia. To, że ma ona takiego patrona, daje szansę na wyraźniejsze zaistnienie w świadomości społecznej przynajmniej raz do roku przy okazji udzielania kościelnego odpustu.

Na początku tego szkicu wspomniałem o Stefanie Czarnowskim jako pierwszym spośród polskich uczonych, który zajął się zagadnieniem roli, jaką spełnia osoba-symbol. Zwrócenie uwagi na społeczną rolę świętych (a dopiero wtórnie ich kultu), aczkolwiek z innej, bo historycznej perspektywy, jest z kolei zasługa innego badacza, aktywnego w okresie międzywojennym, mianowicie - Feliksa Konecznego, którego popularne w założeniu dzieło ukazało się w roku $1937^{14}$. Mimo że cały rozdział poświęca on unitom (grekokatolikom), jego rozważania dotyczą naturalnie Podlasia i Chełmszczyzny. I mimo że nie analizuje też interesujących mnie Mazur i społeczności je zamieszkujących - wówczas wyłączonych z „dziejów narodu polskiego", to jego rozważania stanowią znakomite podłoże dla porównań tradycyjnego stanu tej społeczności sprzed wysiedlenia $\mathrm{z}$ sytuacją dzisiejszą. Można $\mathrm{w}$ tym miejscu ponownie podkreślić, że podobne Czarnowskiemu i Konecznemu przemyślenia i opracowania nie miały szansy zaistnieć przez ponad czterdzieści powojennych lat.

\footnotetext{
${ }^{13}$ Por. U. Janicka-Krzywda, Patron-atrybut-symbol, Poznań 1993.

${ }^{14}$ F. Koneczny, Święci w dziejach narodu Polskiego, Warszawa - Struga - Kraków 1988.
} 
Na badanym przeze mnie rejonie Mazur nie odnotowałem wyraźnych przejawów lokalnej wspólnototwórczej roli kultu świętych. Pozostałości jego dawnej roli można zauważyć w herbach niektórych mazurskich miejscowości: dla Olsztyna jest to postać św. Jakuba Większego (Starszego), dla Olsztynka - Piotra Apostoła. Iława ma w herbie Najświętszą Maryję Pannę z Dzieciątkiem, Pisz głowę św. Jana Chrzciciela na półmisku, a Ostróda - św. Jerzego, męczennika z Liddy ${ }^{15}$. Dla całego regionu czynione są próby rozpowszechniania kultu Brunona Bonifacego z Querfurtu (Kwerfurtu), patrona diecezji łomżyńskiej, którego w 1995 upamiętniono krzyżem w Giżycku. Mimo że jest to postać historyczna ${ }^{16}$, wydaje mi się, iż w obliczu przemian w polskiej religijności restytucja jego kultu nie ma szans na większe powodzenie. Podobne opinie wypowiadają i inni badacze. Etnolog Dariusz Wadowski stwierdza: „Jakkolwiek w doktrynie Kościoła kult świętych nadal jest niezmiernie ważny, to w kulturze współczesnej nie odgrywa tak wielkiej roli, jak w kulturach tradycyjnych. Zdecydowanie zmniejszył się jego zasięg i powszechność, zmieniły się jego formy i funkcje, zniknęło wiele elementów obyczajowych, w które niegdyś obfitował. [...] Jego korzenie tkwią w uniwersalnej potrzebie człowieka naśladowania określonych postaw, oddawania religijnej lub quasi-religijnej czci niektórym postaciom, stanowiącym jeden z ważniejszych czynników budowy tożsamości i integracji" ${ }^{17}$. Mogę stwierdzić, że rola świętych jako symbolu-wzorca do naśladowania zanikła na badanym przeze mnie poziomie mikro, jak się wydaje, nie tylko na Mazurach, gdzie nie był zresztą nigdy rozpowszechniony, tak jak nie była tam rozpowszechniona religia katolicka.

Oficjalną osobą-symbolem dla katolickiej Polski jest św. Wojciech, lecz nawet po jubileuszowych obchodach w 1998 roku nie wydaje się, aby owa postać miała jakieś większe znaczenie dla wzmacniania etnicznej tożsamości Polaków. Można w tym miejscu postawić tezę, iż wykorzystanie symboli-osób świętych dla procedur zawłaszczających etniczną czasoprzestrzeń jest szczególnie silne w przypadku grup, które odczuwają zagrożenie utraty swej tożsamości. Myślę, że podjęcie szerszych, niż miało to miejsce w tym szkicu, studiów porównawczych przyniosłoby wiele kolejnych argumentów na rzecz potwierdzenia takiego sądu.

${ }^{15}$ U. Janicka-Krzywda, dz. cyt., s. 164-165.

${ }^{16}$ Trzydziestopięcioletni męczennik został zamordowany przez Jaćwingów dziewiątego marca 1009 roku, a jego ciało, podobnie jak zwłoki św. Wojciecha, zostały wykupione przez Bolesława Chrobrego. Por. O. H. Hoever, Żywoty świętych Pańskich, Olsztyn 1991, s. 488-490.

${ }^{17}$ Por. D. Wadowski, Wspólnototwórcza rola kultu świętych, w: I. Bukowska-Floreńska (red.), Symbole kulturowe, komunikacja społeczna, społeczności regionalne. Studia, Katowice 1995, s. 94. 


\section{The Saints and the Ethnic and Local Identity (Summary)}

Author analyses the role which the figure of the saint plays in social strategies to maintain national/ethnic and local identities. The saint is a figure known not only in Christianity, thus one must remember that simple comparisons could be misleading. However in any worship: in Hindu religions, in Judaism, in Islam there are persons who are mediators between the Mankind and the Divine. In so-called empirical part of the paper, author describes the examples of St. Partick in Ireland and St. Nicholas in Russia. On the base of his own findings taken from sociological fieldwork on Armenian and Ukrainian groups, either in Poland (Masurian, Ukrainians and Armenian Diaspora) or the Homelands the strength of Armenian saints is shown: St. Mesrop Masthtots, the creator of the unique Armenian alphabet (its 1600 anniversary passed in 2005) and St. Gregory Illuminator, the baptist of the State (301). That role helpful in re-creation of ethnic identity is not fulfilled to such degree for Ukrainian Greek-Catholics in Poland. The analysis of the cities' crests from Masuria region, often showing different saints, demonstrates the same weakness for Polish majority. The positive example of the figure of (elect) Saint would be the Pope John Paul II, uniting the whole Polish nation and being the source of a national proud. 